\title{
The Functions of Discourse Markers in Chinese-English Consecutive Interpreting
}

\author{
ZHAO Zechao, LI Ziang, DENG Jianhua \\ Northeastern University, Liaoning, China
}

\begin{abstract}
The term "discourse markers” (DMs in short) was raised in the 1970s and 1980s. Fraser, a linguist, believes DMs have no truth-conditional meaning which means DMs do not change the prepositional meaning of the sentence. He classifies DMs into three categories: discourse topic markers, discourse activity markers, and message relationship markers. It can be concluded that in conference interpreting, DMs explicit internal structures in three aspects: parallel relation, contractive relation, and elaborative relation based on the analysis of DMs in rendition of Premier Li Keqiang’s press conference from 2014 to 2017.
\end{abstract}

Keywords: discourse markers (DMs), conference interpreting, pragmatic theory

\section{Introduction}

Schiffrin's (1987) promotion of discourse markers (DMs in short) in her book Discourse Markers arouses a sensational effect on the study of discourse markers in linguistics, especially in pragmatics. She defines discourse markers as "sequentially-dependent units of discourse" including and, because, but, I mean, now, oh, or, so, then, well, and y'know. After this, many scholars continue the study from various perspectives in different languages. Some dominant scholars involve Redeker (1991), Blakemore (1992), Fraser (1999), Lenk (1998a; 1998b), and Verschueren (1999). The domestic study of DMs is still at the beginning. Most researchers concentrate on the definition, significance, and functions of DMs based on the previous study of DMs overseas, such as Huang Dawang (2001) and Yin Shulin (2012). Gradually, they analyze DMs from different theories, like Chen Mingyao (2005) takes in coherence-based theory and Mo Aiping (2004) studies DMs by the approach of relevance theory. More recently, the meta-pragmatic approach to analyze DMs draws many scholars' attention, Li Jianxue (2004), for example.

Discourse markers not only play a paramount role in conversation, it also contributes to interpretation. During the interpreting process, DMs can be important devices in connecting segments and guaranteeing successes in communications (Blakemore, 2014). However, few studies concern DM's constructive roles in Chinese-English consecutive interpreting. So, in this paper, based on an analysis of DMs in Chinese-English consecutive conference interpreting, what roles DMs play in interpreting and how to make full use of their functions so as to serve interpreters' output are to be solved for conference interpreting studies and practices. Moreover, for students majoring in interpreting, the paper can draw their attention to the proper utilization of DMs in interpreting so that rendition can be understood sufficiently and effectively.

ZHAO Zechao, Bachelor, English Department, Northeastern University, Liaoning, China.

LI Ziang, Bachelor, English Department, Northeastern University, Liaoning, China.

DENG Jianhua, Master, associate professor, English Department, Northeastern University, Liaoning, China. 


\section{Pragmatic theory by Fraser}

Fraser (1999), based on the analysis of syntactic and semantic aspects of DMs, defines DMs as:

DMs, with the exception of a few idiomatic cases, are expressions drawn from the syntactic classes of conjunctions, adverbials, or prepositional phrases, have the syntactic properties associated with their class membership, have a meaning which is procedural, and have co-occurrence restrictions which are in complementary distribution with their conceptual counterparts. (p. 946)

From syntactic approach, DMs are not from one grammatical category, they can be conjunctions, adverbs, or even prepositional phrases. Semantically, DMs relate two segments but change the propositional meaning of neither of the two segments. They are also procedural which specify how the segment they introduce is to be interpreted relative to the prior, subject to the constraints mentioned earlier. Finally, every individual DM has a specific core meaning.

Fraser (1993) classified three types of discourse markers, namely, message relationship markers, discourse topic markers, and discourse activity markers.

Message relationship markers are those which represent the relationship of the basic information being transported by the current utterance to some prior messages. Four groups are involved including parallel relation, elaborative relation, contrasting relation, and inferential relation. Parallel markers are the commonest discourse markers and mean that the current basic information is parallel to the previous information to a certain degree. This category involves markers, like also, likewise, otherwise, or, by the same token, too, alternatively, similarly, analogously, and, correspondingly, and equally. One example is given to demonstrate their function better:

Example 1:

A: My mother works in a bank and my father works in a hospital.

B: And where do you work?

In Example 1, the DM and, initiated by the Speaker B, represents information parallel to the previous two, which means the latter information is also required. And here as a DM distinguish itself from the coordinate conjunction and. In sentence like "Air and water are basic for our life", and owns sentence propositional meaning.

The second group of message relationship markers is called contrastive discourse markers. The first subgroup of it represents sharp contrast including on the contrary, in contrast, contrariwise, conversely, on the one/other hand, and in comparison. The second subgroup embodies a sharp but unexpected contrast. This category contains DMs, like yet, despite, nevertheless, regardless, however, rather, instead, in spite of, still, though, nonetheless, all the same, and some others.

Another subgroup contains that said and I may be wrong but, which suggests a conflict lies in a prior statement (by either the speaker or another discourse participant) and the current claim. In Fraser's view, well belongs to a sole subgroup which means the current message is the opposite of what the listener is supposed to expect.

Another group of message relationship markers is elaborative markers, which means the current utterance consists of an elaboration to the previous one. This group includes what is more, that is, moreover, namely, more importantly, more accurately, more specifically, more precisely, above all, more to the point, for instance, for example, further(more), besides, better, in addition, also, in fact, in other words, in particular, and indeed. 
Fraser (1993, p. 13) further classifieds these markers according to the rules below:

The first subgroup means a more general elaboration, this group including DMs indeed, the markers above all, of these, on top of it all, to top it all off and in fact. Another group means DMs signify complement to the current statement containing what is more, moreover, in addition, furthermore, and besides. (e.g. "I don't think your parents like him. In addition, I don't like him.”) The third subgroup marking a more refined description of the sense of the foregoing, contains more precisely, more specifically, more accurately, in particular, more importantly, more to the point. A final subgroup signals the speaker tends to illustrate for the earlier message. Namely, for instance, for example and in other words belong to this subgroup.

The last group is inferential markers which indicate the current utterance carries a message that is consequential to the foregoing one to some degree. This category owns thus, therefore, so, as a result, hence, as a consequence, accordingly, consequently, and in this/that case. Besides, this category has no evident subgroups.

Discourse topic markers contain two subgroups, one owns the function of reemphasis on the current topic and the other signifies a concentration or emphasis on part of the present topic. The first subgroup includes with regards to, that reminds me, speaking of, listen, in any case, in case you do not recall, to continue, to return to my original point, by the way, and so on while the second subgroup of topic markers contains well, OK, indeed, look (here), in fact, here, again, alright, but, listen, now, say, see, and y'see.

Discourse activity markers mean the current discourse activity is related to some part of the previous topic. These activities refer to types of discourse work, such as explaining or summarizing, and not to the type of message (e.g., a claim or a promise) the speaker conveys through the utterance. Seven types of discourse activity include clarifying (to clarify), conceding (anyway, after all, besides), explaining (to explain, if I may explain,), interrupting (if I may interrupt), repeating (to repeat, once again), sequencing (in the first place, to continue, to conclude), and summarizing (in summary, to sum up,).

\section{Explicitation of Internal Structure}

Explicitation of internal structure means the interpreter makes efforts to make implicit relations among utterances within the discourse explicit. Employment of DMs can be regarded as a useful technique to facilitate the audience's understanding of the intended information.

In accordance with Fraser's category of DMs, DMs utilized by the interpreter are conducive to explicate parallel relation, contrastive relation and elaborative relation.

\section{Parallel Relation}

Compared to other DMs, and, in most cases, displays the parallel relation in rendition. The next two examples illustrate the function of the DM and in terms of explicating the internal structure.

Example 2:

$\mathrm{Li}$ : 我们之所以要有 $6.5 \%$ 左右的经济增速, 稳增长最主要还是要保就业。因为就业对我们这样一个 13 亿多人口的大国来说是最大的民生。就业是经济发展的基础, 是财富增长的来源, 也是居民收入的主 渠道。

Interpreter: The fact is that we have projected around 6.5\% GDP growth mainly to support job creation. Employment is of paramount importance for such a large country as China with 1.3 billion-plus people. And employment is the foundation of economic development. It creates wealth and is a major source of household income. 


\section{Example 3:}

$\mathrm{Li}$ : “双创” 不仅带动了大量就业, 促进创新驱动发展战略深入实施, 它也是一场改革, 因为它抓 住了“人”这个生产力当中最重要的因素。

Interpreter: This initiative has generated a great deal of jobs. It is also an important means to implement the strategy of innovation-driven development. And, this initiative is a process of reform too because it captures the most important element in productive forces, that is, human resources.

In Examples 2 and 3, the DM and represents parallel relation. In Example 2, what and connects is the two aspects of the importance of employment. In Example 3, and demonstrates two parallel relation, that is “双创” could deepen the development of innovation-drive and press ahead reform. Generally speaking, DM and possesses the function of linking two parallel components in discourse.

\section{Contrastive Relation}

Fraser (1999) classified contrastive DMs into three groups, namely, representing sharp contrast, embodying sharp but unexpected contrast, and the contrast between previous and current statements. However, in conference interpreting, owing to the formalness and solemnity, not all types of contrast can be seen frequently, where but and well are main DMs revealing contrastive relation.

Example 4:

$\mathrm{Li}$ : 我们的确已经完成了本届政府成立之初确定的任务, 但是在推进的过程中发现这里面的名堂多 了, 不仅是审批权, 还有名目繁多的行政许可、资格认证、各种奇苑证明, 让企业不堪重负的收费等等, 这些都属于简政放权要继续推进的内容。

Interpreter: This reform cannot be accomplished overnight. You are right that my government's target for cutting the number of government review items has already been met. But in this process, we have encountered a variety of issues unexpectedly. In addition to government review and approval items, there are all sorts of procedures requiring administrative permits, certification of qualifications, and payment of all kinds of administrative fees.

In Example 4, before the DM but, Premier Li claims that the government has finished its goal in terms of streamlining administration. However, after but, he states we still continue the reform on account of the unexpected issues. So, the main idea of Premier Li's statement is the government will deepen reform in respect of streamlining administration, forming a sharp contrast to the former utterance.

Example 5:

$\mathrm{Li}$ : 我在政府工作报告当中讲了五条措施, 会坚定地向前推进, 真正打一场 “蓝天保卫战”。但是 也坦率地告诉各位, 这需要有一个过程。

Interpreter: In my government work report, I laid out five key measures for smog control and we will push them through with full determination to fight and win the battle on smog. But to be honest with you, that will take time.

When asked about smog, Premier Li tells us that our government will keep fighting with smog. However, what but initiates is fighting with smog is a tough task. So, Premier Li conveys the message that we will take measures to fight with air pollution successively, but it is not east to achieve the goal of a blue and clear sky. Thus, but in the rendition provides a converse information.

Except but, the DM well bears the function of forming contrast. The following example embodies the function of revealing contrastive relation of DM well. 
Example 6:

$\mathrm{Li}$ : 这 3 年多来, 每天平均有 4 万个以上市场主体注册登记, 相当于每年新增 1000 多万个。我和有些 外国的领导人并不是小国谈到这件事, 他们很惊讶, 这相当于他们国家中小微企业的总量。其实 “双创” 不仅是中小微企业的事，也是大企业的事。

Interpreter: Over the past three years and more, on an average daily basis, more than 40,000 market entities have got registered, adding up to 10 million every year. When I share this figure with foreign leaders, they were truly amazed as this is equivalent to the total number of SMEs in their countries. Well, not only small medium enterprises (SMEs) are doing entrepreneurial and innovation activities. Big companies are actively engaged in this too.

This paragraph talks about the infinite power of small and micro enterprises in business innovation. However, in the final utterance, Premier Li also stresses that not only SMEs contribute to the development of business innovation, big companies should also share the responsibility, which corrects the information that SMEs are the sole drive to push business innovation.

\section{Elaborative Relation}

According to Fraser's (1993) generalization, the elaborative DMs can be further classified. They can be served as a more general elaboration (see Example 7), signal an additional aspect of current topic (see Example 8), or provide an illustration to the earlier point (see Example 9).

Example 7:

$\mathrm{Li}$ : 两岸的和平发展确实给两岸同胞带来了很多新的机遇。据不完全统计, 每年大概有500万台湾同 胞往返于大陆和岛内。我们会出台更多政策让台湾同胞在大陆就业、创业、工作、生活, 享受一家人便 利条件。对台商来大陆投资, 我们是欢迎的。我记得在记者会上曾经有人提出, 希望继续保持对台商投 资的优惠政策。我重申: 我们会继续提供优惠, 让台商、台湾同胞和大陆一起共享发展的机遇。终归我 们是一家人。

Interpreter: The peaceful growth of Cross-Straits relations has brought new opportunities for people on both sides. According to current statistics, people on Taiwan make 5 million visits across the Straits every year. We will introduce more policies to provide more convenience for people in Taiwan to work and live on the mainland as family. We welcome investment from Taiwan businesses. I recall that at last year's press conference, I was asked whether the mainland will keep preferential policies toward Taiwan businesses. I wish to reiterate here that such policies will be maintained to enable Taiwan businesses and people to share in China's development opportunities with their compatriots on the mainland. After all, we are one family.

The DM after all signals a more general sense of the utterance. The government's policies towards Taiwan are elaborative examples of the last sentence, that is we are one family explains why the government implements the policies and summarizes the previous information.

Example 8:

$\mathrm{Li}$ : 我们这样做符合经济规律, 也可以使注意力更多地放到提高质量和效益上来, 对世界经济增长 的贡献率不会低。

Interpreter: The measures we take are consistent with the laws of economics. Moreover, slower growth can help us better focus on enhancing the quality and performance of China's economy. I do not think China's contribution to global growth will come down. 
The background information of Example 8 is the journalist asks Premier Li whether the goal of achieving $6.5 \%$ growth of economic is lower than average. Li gives two reasons: The first is it complies with the laws of economics and the second is it will focus on quality and efficiency. The interpreter uses the DM moreover to explain why the government sets the goal of $6.5 \%$ growth rate, which is an additional reason.

Example 9:

$\mathrm{Li}$ : 这几年我们一直处在新成长劳动力的高峰, 今年的就业压力仍然比较大, 光高校毕业生就达795 万, 创历史新高, 还有 500 万左右的中职毕业生, 加上去过剩产能需要安置几十万转岗职工等等。

Interpreter: In the past several years, record numbers of job-seekers have entered the labor force, which is a big challenge for us. For example, this year, we are going to have 7.95 million college graduates, the highest number in history. Five million will graduate from secondary vocational schools and several hundred thousand workers will be laid off in the process of cutting overcapacity.

We can find that there is no such words, like “例如” and “比如说” in Premier Li's utterance. However, the interpreter adopts the DM for example to signal an illustration of “今年的就业压力仍然比较大”. DMs like for example are added by the interpreter to help the audience understand the relation between proceeding utterance and the earlier one.

Although Chinese and English share some similarities, their differences are distinct. English is a language which involves in abstract and analytical thinking with linear way whereas Chinese is more comprehensive and curving. This makes interpreting a tough task. Hence, the interpreters often adopt DMs, like so, moreover, and but to explicate the internal structure of the speaker's words so that the logic of the rendition can be obvious and intelligible.

\section{Conclusion}

In conference interpreting, DMs helps the audience understand the invisible meanings underlying the utterances. These invisible meanings refer to internal structure including parallel relation, contrastive relation, and elaborative relation. Therefore, interpreters can adopt DMs in their rendition so that the audience can be access to the meaning easily.

\section{Reference}

Blakemore, D. (1992). Understanding Utterances. Oxford: Blackwell.

Blakemore, D. (2014). Discourse markers in free indirect style and interpreting. Journal of Pragmatics, 60, 106-120.

Chen, M. Y. (2005). On Discourse Coherence and the Translation of Discourse Markers. Shanghai Journal of Translators, (4), 20-23.

Fraser, B. (1999). What are discourse markers? Journal of Pragmatics, 31, 931-952.

Fraser, B. (1993). Discourse Markers Across Language. Pragmatics and Language Learning, (4), 2-16.

Huang, D. W. (2001). A Review of Discourse Markers. Foreign Languages In Fujian, (1), 5-11.

Lenk, U. (1998). Marking discourse coherence. Tubingen: Narr.

Lenk, U. (1998). Discourse markers and global coherence in conversation. Journal of Pragmatics, 30, 245-257.

Li, J. X. (2004). The study of the relation between discourse markers and meta-pragmatic strategies. Foreign Language Education, (6), 4-8.

Mo, A. P. (2004). A Relevance-based Approach to Discourse Markers. Language and Translation (Chinese), (3), 3-8.

Redeker, G. (1991). Linguistic markers of discourse structure. Linguistics, 29(6), 1139-1172.

Schiffrin, D. (1987). Discourse markers. Cambridge: Cambridge University Press.

Verschueren. (1999). Understanding pragmatics. London: Edward Arnold.

Yin, S. L. (2012). The Features and Definition of Discourse Markers. FOREIGN LANGUAGE RESEARCH, (3), 91-95. 